\title{
NILAI TUKAR DAN OUTPUT SEKTOR MANUFAKTUR DI NIGERIA
}

\author{
Dodi Chandra \\ Sekolah Tinggi Ilmu Sosial dan Ilmu Politik Persada Bunda \\ Email: dodi01@gmail.com
}

\begin{abstract}
Abstrak
Studi ini secara empiris menyelidiki dampak nilai tukar terhadap output sektor manufaktur di Nigeria. Rangkaian waktu tahunan yang mencakup periode antara 1980 dan 2016 dikumpulkan untuk studi ini. Variabel yang digunakan untuk mengeksplorasi hubungan antara nilai tukar dan output sub-sektor manufaktur adalah; hasil produksi manufaktur, nilai tukar, ekspor manufaktur dan tingkat bunga. Metode yang digunakan adalah Error Correction Mechanism (ECM). Sementara itu, uji akar unit untuk stasioneritas dan uji kointegrasi untuk hubungan ekuilibrium jangka panjang mendahului ECM. Hasil uji akar unit ADF dan uji kointegrasi Johansen menunjukkan bahwa semua variabel stasioner dan memang kointegrasi. Dari hasil mekanisme koreksi kesalahan yang pelit, dapat diambil kesimpulan sebagai berikut; $\mathrm{R}^{2}$ adalah $61 \%$, artinya model dinamis cocok. Nilai tukar dan tingkat bunga berhubungan negatif dengan output sub-sektor manufaktur di Nigeria. Sedangkan ekspor manufaktur memiliki hubungan positif dengan output sektor manufaktur. Hasil penelitian menunjukkan bahwa penurunan output sektor manufaktur merupakan cerminan dari nilai tukar yang tidak stabil dan tingkat suku bunga yang tinggi. Studi merekomendasikan agar pemerintah merumuskan dan melaksanakan kebijakan moneter yang bertujuan untuk menurunkan suku bunga pada sub-sektor manufaktur dan kebijakan nilai tukar yang menguntungkan untuk mencapai sub-sektor manufaktur yang layak.
\end{abstract}

Kata Kunci: Nilai Tukar, Manufaktur, Suku Bunga, Ekspor, Kebijakan dan Output.

\begin{abstract}
The study empirically investigates the impact of the exchange rate on the output of the manufacturing sector in Nigeria. Annual time series covering the period between 1980 and 2016 were collected for this study. The variables used to explore the relationship between the exchange rate and the output of the manufacturing sub-sector are; manufacturing output, exchange rates, manufactured exports and interest rates. The method used is the Error Correction Mechanism (ECM). Meanwhile, the unit root test for stationarity and the cointegration test for long-run equilibrium relationships preceded ECM. The results of the ADF unit root test and the Johansen cointegration test show that all variables are stationary and indeed cointegration. From the results of the stingy error correction mechanism, the following conclusions can be drawn; $R^{2}$ is $61 \%$, meaning that the dynamic model is suitable. The exchange rate and interest rate are negatively related to the output of the manufacturing sub-sector in Nigeria. Meanwhile, manufactured exports have a positive relationship with the output of the manufacturing sector. The results showed that the decline in the output of the manufacturing sector was a reflection of an unstable exchange rate and high interest rates. The study recommends that the government formulate and implement monetary policies aimed at lowering interest rates in the manufacturing sub-sector and favorable exchange rate policies to achieve a viable manufacturing sub-sector.
\end{abstract}

Keywords: Exchange Rate, Manufacturing, Interest Rates, Exports, Policy and Output. 


\section{A. PENGANTAR}

Struktur ekonomi mengacu pada totalitas hubungan kompleks yang ada antara sumber daya ekonomi dan keluaran yang dihasilkan dari sumber daya. Sumber daya ini dieksplorasi oleh berbagai unit atau sektor ekonomi. Unit tersebut termasuk manufaktur dan sektor keuangan. Sub-sektor manufaktur merupakan unit ekonomi yang sangat diperlukan dalam hal pemanfaatan sumber daya. Sektor manufaktur adalah mesin pertumbuhan dan pembangunan ekonomi karena mendiversifikasi ekonomi dan membuatnya lebih luas. Selain itu, perantara keuangan yang efisien dan mobilisasi sumber daya adalah kunci pembangunan ekonomi negara mana pun dan peran ini adalah tanggung jawab sektor keuangan suatu perekonomian. Sektor tersebut menyediakan dana sebagai input modal pada sektor perekonomian lainnya khususnya sub sektor manufaktur.

Menurut Fakiyesi (2005), sektor manufaktur berperan sebagai katalisator dalam perekonomian modern dan memiliki banyak manfaat yang sangat penting bagi transformasi ekonomi. Dalam ekonomi maju, sektor manufaktur adalah sektor unggulan dalam banyak hal. Ini berfungsi sebagai sumber peningkatan produktivitas dalam kaitannya dengan substitusi impor dan ekspansi ekspor, menciptakan kapasitas pendapatan devisa, meningkatkan kesempatan kerja dan merangsang perkembangan spekulasi pada tingkat yang lebih cepat daripada segmen ekonomi lainnya, dan lebih luas dan lebih efisien. Keterkaitan antar sektor yang berbeda. Tetapi ekonomi Nigeria berada di bawah industri dan pemanfaatan kapasitasnya juga rendah. Sektor manufaktur semakin bergantung pada sektor luar negeri untuk mengimpor input non-tenaga kerja sejauh ketidakmampuan untuk mengimpor sebagai akibat dari variabilitas nilai tukar dapat berdampak negatif pada produksi manufaktur (Okigbo, 1993). Serupa dengan itu, Oyejide dan Ogun (1985) berteori bahwa runtuhnya Sistem Bretton Woods mendorong fluktuasi nilai tukar secara global di mana Nigeria tidak ketinggalan. 
Menurut Opaluwa, Umeh dan Abu (2010), bagaimanapun, telah diamati bahwa mulai tahun 1980-an perusahaan manufaktur di Nigeria mengalami stagnasi relatif. Hal ini karena ketidakmampuan mereka untuk mengatasi tantangan yang ditimbulkan oleh lingkungan operasi yang keras di Nigeria; yang meliputi masalah pengelolaan nilai tukar dan kerusakan infrastruktur. Dengan demikian, ketidakefektifan dalam pengelolaan nilai tukar telah berkontribusi besar pada rendahnya output dan pemanfaatan kapasitas sektor manufaktur di Nigeria.

Sementara itu, selama bertahun-tahun, pemerintah federal Nigeria telah melakukan upaya panik melalui bank apex dan manajemen moneter untuk membendung gelombang pasang fluktuasi nilai tukar. Terlepas dari berbagai upaya yang dilakukan oleh pemerintah Nigeria untuk mempertahankan nilai tukar yang stabil, naira terus mengalami depresiasi dari N0,61 pada tahun 1981 menjadi N 2,02 pada tahun 1986, N 7,901 pada tahun 1990, semuanya terhadap satu dolar AS. Strategi deregulasi terpandu atau pengawasan mematok naira pada N21.886 pada tahun 1994, N86.322 pada tahun 1999 dan N 135,50 pada tahun 2004. Setelah itu, nilai tukar meningkat menjadi N132.15 pada tahun 2005 dan kemudian N 118.57 pada tahun 2008. Menjelang akhir tahun ini, naira terdepresiasi ke N150.0124 pada tahun 2009 dan saat ini pada tanggal 2 Agustus 2013 nilai tukar satu dolar AS ke naira adalah N160.14756 (CBN, 2014). Namun pada bulan Oktober 2016, nilai tukar satu dolar AS terhadap naira di pasar paralel adalah sekitar N 500.00 (CBN, 2017).

Namun, sangat sedikit pencapaian yang dicapai dalam menstabilkan nilai tukar. Akibatnya, masalah variasi nilai tukar terus berlanjut selama masa studi. Berdasarkan argumen di atas, tujuan utama dari studi ini adalah untuk menguji pengaruh nilai tukar terhadap output sektor manufaktur di Nigeria. Dengan cara yang sama, variabel penting lainnya seperti hubungan antara ekspor manufaktur; suku bunga dan output sektor manufaktur diperiksa. Bagian lain dari makalah ini membahas kerangka teori, literatur empiris, metodologi, hasil dan diskusi, kesimpulan dan rekomendasi. Landasan teori JURNAL PAPATUNG: Vol. 2 No. 1 Tahun 2019 
dari penelitian ini adalah teori PPP. Hal ini karena berkaitan dengan masalah ekspor dan nilai tukar yang merupakan variabel penjelas penting yang digunakan dalam penelitian untuk menentukan output sektor manufaktur di Nigeria. Jadi, Purchasing Power Parity (PPP) hanya menyatakan itu satu unit uang tunai tertentu harus memiliki kapasitas untuk membeli sejumlah barang dagangan yang sama di semua negara. Banyak analis pasar percaya bahwa PPP menggambarkan kekuatan yang menentukan nilai perdagangan dalam jangka panjang. Dengan tepat, skala pertukaran yang nyata antara mata uang dua negara harus mencerminkan tingkat biaya yang beragam di negaranegara tersebut. PPP, yang membentuk blok bangunan yang kuat dari teori penentuan nilai tukar, menyatakan bahwa terdapat hubungan proporsional antara nilai tukar mata uang dua negara dan tingkat inflasi relatifnya.

Teori ini didasarkan pada hukum satu harga, yang menjelaskan bahwa, dengan tidak adanya hambatan perdagangan dan biaya transportasi, arbitrase komoditas spasial memastikan bahwa harga suatu barang disamakan di berbagai negara. Teori PPP dapat dirumuskan dalam dua bentuk: dalam bentuk absolut. Bentuk absolut PPP menegaskan bahwa nilai tukar ekuilibrium menyamakan daya beli umum dari pendapatan tertentu dalam hal tingkat harga relatif. Dengan demikian, ini menghubungkan tingkat nilai tukar dengan tingkat harga relatif. Bentuk relatif menyatakan bahwa perubahan nilai tukar yang diukur dari periode dasar mencerminkan perubahan tingkat harga relatif. Relevansi teori PPP dengan penelitian ini adalah teori yang menganjurkan nilai tukar ekuilibrium rasio tingkat harga domestik terhadap luar negeri, yang ditentukan oleh hubungan antara impor dan ekspor negara. Jadi, mata uang domestik harus kuat dalam hubungannya dengan mata uang asing untuk perdagangan yang menguntungkan yang pada gilirannya berfungsi sebagai kebutuhan untuk mencapai tingkat pertumbuhan yang ditargetkan. 


\section{B. PEMBAHASAN}

Beberapa ahli telah menyelidiki hubungan antara nilai tukar dan sektor manufaktur. Juga, bukti empiris yang mendukung efek langsung atau tidak langsung yang sistematis dari stabilitas nilai tukar pada perdagangan dan pertumbuhan di negara berkembang tetap beragam. Sementara itu, karya empiris berikut diteliti. Eme dan Johnson (2012) meneliti dampak ukuran pertukaran terhadap pengembalian riil di Nigeria selama periode 1986-2010. Hasilnya menunjukkan bahwa tidak ada bukti hubungan langsung yang kuat antara perubahan dalam skala pertukaran dan pengembangan hasil. Secara relatif, perkembangan keuangan Nigeria secara khusus dipengaruhi oleh faktor-faktor terkait uang. David, Umeh dan Ameh (2010) juga meneliti pengaruh fluktuasi nilai tukar terhadap industri manufaktur Nigeria. Mereka menggunakan alat ekonometrik regresi berganda yang menemukan hubungan negatif antara nilai tukar yang tidak dapat diprediksi dan kinerja sektor manufaktur.

Asher (2012) juga meneliti pengaruh volatilitas nilai tukar terhadap kinerja makroekonomi di Nigeria dari tahun 1980 - 2010. Mereka menemukan bahwa nilai tukar berhubungan positif dengan Produk Domestik Bruto. Demikian pula, Owolabi dan Adegbite (2012) menganalisis dampak administrasi perdagangan luar negeri terhadap perkembangan industri di Nigeria dari tahun 1985 hingga 2005. Kajian ini menemukan bahwa nilai tukar berpengaruh signifikan terhadap pertumbuhan ekonomi dengan R2 yang disesuaikan sebesar 69\%. Akinlo dan Lawal (2015) meneliti pengaruh nilai tukar terhadap industri modern di Nigeria selama periode 1986-2010. Hasil review dengan memanfaatkan Vector Error Correction Model (VECM), menegaskan adanya hubungan jangka panjang antara industri modern, nilai tukar, cash supply dan tingkat harga. Selain itu, penurunan nilai tukar tidak memiliki efek yang terlihat pada industri modern dalam jangka pendek, namun memiliki efek positif dalam jangka panjang. Jongbo (2014) mempelajari dampak fluktuasi nilai tukar riil terhadap output industri di Nigeria. Hasilnya menunjukkan bahwa tingkat konversi riil berperan penting dalam menentukan 
hasil industri. Selain itu, aksesibilitas peningkatan perdagangan luar negeri melalui dorongan ekspor yang tidak menyenangkan baik dari barang-barang minyak maupun non-minyak akan memberikan kontribusi yang besar terhadap peningkatan hasil industri. Kajian tersebut juga mengungkap bahwa pemanfaatan kapasitas rendah yang mungkin tidak terlalu jauh dari, catu daya yang agak epilepsi, kurangnya teknologi yang memadai dan tepat.

Ehinomen dan Oladipo (2012) meneliti dampak manajemen nilai tukar terhadap pertumbuhan sektor manufaktur di Nigeria. Studi ini mencakup periode 1986-2010 dengan menggunakan data deret waktu. Analisis regresi berganda Ordinary Least Square (OLS) digunakan. Hasil empiris dari penelitian ini menunjukkan bahwa devaluasi yang menjadi dasar kebijakan SAP pada tahun 1986, dan periode yang disurvei tidak memiliki hubungan yang berarti dengan produktivitas manufaktur. Juga ditemukan bahwa apresiasi nilai tukar Nigeria memiliki korelasi yang substansial dengan output domestik. Ini pada gilirannya akan mendorong pertumbuhan di sektor tersebut. Selain itu, juga ditemukan dari garis regresi yang dinilai bahwa terdapat hubungan positif antara produk domestik bruto manufaktur dan inflasi.

Ogunleye (2008) meneliti dampak deregulasi nilai tukar terhadap kinerja industri di Nigeria antara tahun 1975-2008. Dia menggunakan teknik kointegrasi dan tes Choose breakpoint sebagai alat analisis. Dua ukuran kinerja industri; Tingkat pertumbuhan produktivitas industri dan rasio produksi industri terhadap PDB digunakan. Dia menemukan bahwa dalam jangka panjang, ada hubungan antara masing-masing ukuran ini di satu sisi dan nilai tukar, tingkat bunga, dan syarat perdagangan di sisi lain. Secara spesifik, deregulasi nilai tukar ternyata berdampak positif signifikan terhadap kinerja industri. Selain itu, untuk menentukan dinamika jangka pendek di sekitar hubungan ekuilibrium, studi memperkirakan model korelasi kesalahan (ECM) pada tingkat pertumbuhan produktivitas industri dan kontribusi tingkat pertumbuhan produktivitas industri di Nigeria. 
Akinlo dan Adejumo (2014) menyelidiki dampak volatilitas nilai tukar terhadap ekspor nonmigas di Nigeria dan menemukan bahwa volatilitas nilai tukar memiliki pengaruh positif dan signifikan terhadap ekspor nonmigas dalam jangka panjang sedangkan dampak jangka pendek volatilitas nilai tukar secara statistik tidak signifikan. Implikasi kebijakan adalah bahwa volatilitas nilai tukar hanya efektif dalam jangka panjang tetapi tidak dalam jangka pendek dalam perekonomian Nigeria. Imoughele dan Ismila (2015) meneliti dampak nilai tukar terhadap ekspor nonmigas. Data time series yang diperoleh dari CBN untuk periode 27 tahun yaitu 1986 hingga 2013 digunakan. Uji Augmented Dickey-Fuller (ADF) digunakan untuk uji akar unit dan uji kointegrasi Johansen juga dilakukan untuk membangun hubungan jangka pendek dan jangka panjang antara ekspor nonmigas dan variabel independen. Hasilnya menunjukkan tiga kondisi koordinasi yang mengatur adanya hubungan jangka panjang di antara faktorfaktor tersebut. Prosedur terukur OLS digunakan untuk mensurvei determinan perdagangan non-minyak di Nigeria. Hasil penelitian menunjukkan bahwa nilai tukar efektif, suplai uang tunai, kredit ke segmen swasta dan eksekusi moneter secara signifikan mempengaruhi perkembangan ekspor nonmigas dalam perekonomian Nigeria dan valuasi skala konversi berdampak negatif pada perdagangan nonmigas yang stabil.

Ajayi (2012) dalam penyelidikan tentang runtuhnya pangsa manufaktur Nigeria pada perkembangan moneter. Dia menggunakan garis besar penelitian cross-sectional dan menemukan bahwa pendorong utama penurunan di divisi perakitan Nigeria adalah rendahnya penggunaan rencana pengeluaran Nigeria terutama di wilayah kerangka kerja. Ini menyiratkan penggunaan pendekatan keuangan yang rendah mempengaruhi tingkat pembangunan di area manufaktur Nigeria. Tomola, Adebisi dan Olawale (2012) menggunakan teknik kointegrasi dan vektor error correction model (VECM) untuk memutuskan hubungan antara pinjaman bank, pengembangan moneter dan area manufaktur di Nigeria. Temuan dari tinjauan tersebut mengungkapkan bahwa JURNAL PAPATUNG: Vol. 2 No. 1 Tahun 2019 
penggunaan batas produksi dan tingkat pinjaman bank sama sekali mempengaruhi hasil produksi di Nigeria. Artinya perkembangan hasil manufaktur belum cukup untuk menghasilkan perkembangan yang cukup besar dalam perekonomian.

\section{Justifikasi Studi dan Kesenjangan}

Sektor manufaktur memainkan peran katalitik dalam ekonomi modern dan memiliki banyak manfaat yang sangat penting untuk transformasi ekonomi. Dalam ekonomi maju, sektor manufaktur merupakan sektor unggulan dalam banyak hal. Ini berfungsi sebagai sumber peningkatan produktivitas dalam kaitannya dengan substitusi impor dan perluasan ekspor, menciptakan kapasitas penghasil devisa, meningkatkan kesempatan kerja. Selain itu, karya empiris para sarjana terkemuka di bidang studi ini juga telah diperiksa dengan cermat. Secara khusus, karya Imoughele dan Ismila (2015); Akinlo dan Lawal (2015); Akinlo dan Adejumo (2014); dan Adewuyi (2006) patut dipuji.

Dengan latar belakang ini, penelitian ini bertujuan untuk memberikan wawasan empiris tentang dampak nilai tukar pada sektor manufaktur di Nigeria dengan menggunakan teknik ECM untuk menganalisis data tahunan yang mencakup dari 1980 hingga 2016. Selain itu, penelitian ini mengadopsi nilai tukar, ekspor manufaktur dan suku bunga untuk menjelaskan output dari sektor manufaktur di Nigeria. Dengan demikian, studi ini berbeda dari yang lain karena mengkaji dampak ekspor produk manufaktur terhadap output sektor manufaktur. Tidak seperti studi empiris lain yang meneliti hubungan antara ekspor agregat Nigeria dan output sektor manufaktur. Penelitian ini memanfaatkan data deret waktu yang berkaitan dengan variabel yang diteliti. Studi penelitian dianggap sebagai data sekunder waktu dari 1980-2016. Data tersebut bersumber dari laporan dan laporan tahunan Bank Sentral Nigeria. Juga, ekonometrik akar unit, kointegrasi dan mekanisme koreksi kesalahan digunakan untuk analisis. 


\section{Uji Unit Root}

Argumen dasar dari prosedur Johansen adalah bahwa barisan matriks variabel dapat digunakan untuk menentukan apakah kedua variabel tersebut terintegrasi atau tidak. Kurangnya kointegrasi menunjukkan bahwa variabel tersebut tidak memiliki hubungan jangka panjang. Johansen (1998) bentuk umum dari kointegrasi diberikan dengan Manpt $=\mu+1$ ManPt-1 + - - + $\Delta$ P ManPt-p + Ut (ii)

Dimana: ManPt adalah vektor nx1 dari variabel yang terintegrasi dari orde yang biasa dilambangkan dengan (1) dan $\mathrm{U}$ t adalah vektor nx1 dari inovasi.

\section{Model Koreksi Kesalahan}

Jika kointegrasi telah dipastikan dalam suatu model, maka tahap selanjutnya membutuhkan penataan Error Correction Mechanism (ECM) untuk memodelkan hubungan dinamis. Tujuan ECM adalah untuk menunjukkan kecepatan penyesuaian dari ekuilibrium jangka pendek ke kondisi ekuilibrium jangka panjang. Semakin besar koefisien parameter, semakin tinggi kecepatan penyesuaian model dari jangka pendek ke jangka panjang.

Persamaan untuk ECM dirumuskan sebagai berikut:

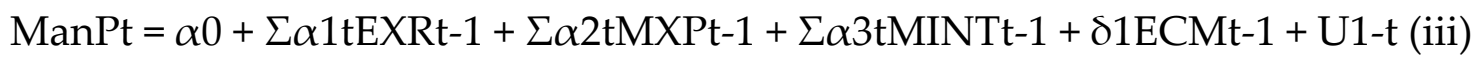

Dimana: ManP adalah Output Sektor Manufaktur, EXR adalah Nilai Tukar, MXP adalah Ekspor Manufaktur, MINT adalah Suku Bunga, U adalah istilah kesalahan, parameter $\alpha$, dan $\delta 1$ koefisien ECM.

A Priori Expectations: Diharapkan, secara teoritis $\alpha 1<0, \alpha 2>0 ; \alpha 3<0$

\section{Uji Akar Unit untuk Stasioneritas (Augmented Dickey Fuller)}

Uji ADF digunakan untuk menyelidiki stasioneritas variabel. 
ARTIKEL

Tabel 1 Uji Akar Unit untuk Stasioneritas (Augmented Dickey Fuller)

\begin{tabular}{|c|c|c|c|c|c|}
\hline \multirow{2}{*}{ Variabel } & Tes ADF & \multicolumn{3}{|c|}{ Nilai-Nilai Kritis } & $\begin{array}{c}\text { Urutan } \\
\text { Integrasi }\end{array}$ \\
\cline { 2 - 5 } & & $\mathbf{1 \%}$ & $\mathbf{5 \%}$ & $\mathbf{1 0 \%}$ & \\
\hline ManP & -5.113252 & -3.653730 & -2.957110 & -2.617434 & Order one \\
\hline EXR & -5.455726 & -3.646342 & -2.954021 & -2.615817 & Order one \\
\hline MXP & -5.207182 & -3.646342 & -2.954021 & -2.615817 & Order one \\
\hline MINT & -4.917156 & -3.653730 & -2.957110 & -2.617434 & Order one \\
\hline
\end{tabular}

Persamaan ADF dimana uji ADF lebih besar dari nilai kritis disajikan demikian; $5.113252(\mathrm{ManP})=-5.455726(\mathrm{EXR})-5.207182(\mathrm{MXP})-4.917156(\mathrm{MINT})+\delta \mathrm{t}$. Hasil uji akar unit stasioneritas yang disajikan pada Tabel 1 menunjukkan bahwa semua variabel stasioner dengan tingkat stasioneritas 1\% ,5\% dan 10\%. Meskipun tidak ada variabel yang diam pada orde nol. Sejalan dengan Granger dan New bold (1974), variabel nonstasioner dibedakan satu kali untuk mencapai stasioneritas. Oleh karena itu ManP (Output sektor manufaktur), EXR (nilai tukar), ekspor manufaktur (MXP) dan suku bunga (MINT) menjadi stasioner pada urutan pertama. Hal ini dikarenakan nilai ADF masing-masing variabel lebih besar dari nilai kritis yaitu 1\%, 5\% dan 10\%.

Tabel 2 Hasil Uji Kointegrasi Johansen

\begin{tabular}{|c|c|c|c|l|}
\hline Nilai eigen & Statistik Jejak & $5 \%$ nilai kritis & Masalah. ** & $\begin{array}{l}\text { Hipotesis CE } \\
(\mathrm{s})\end{array}$ \\
\hline 0.867688 & 121.7847 & 47.85613 & 0.0000 & Tidak ada * \\
\hline 0.729422 & 61.10693 & 29.79707 & 0.0000 & Maksimal 1 * \\
\hline 0.517903 & 21.89112 & 15.49471 & 0.0047 & Maksimal 2 * \\
\hline 9.37E-05 & 0.002811 & 3.841466 & 0.9551 & Maksimal 3 \\
\hline
\end{tabular}

Persamaan kointegrasi Johansen untuk persamaan pertama disajikan demikian; 121,7847 $=0,867688+47,85613+\ldots \ldots \ldots . . \mathrm{Ut}$ 
Hasil uji kointegrasi Johansen seperti yang disajikan pada Tabel 2 menunjukkan bahwa terdapat tiga persamaan kointegrasi pada taraf signifikansi 5\%. Ini karena Trace Statistic lebih besar dari nilai kritis yaitu 5\%. Alasan keberadaan persamaan kointegrasi ini tidak jauh dari adanya uji akar unit pada orde satu. Oleh karena itu, terdapat hubungan jangka panjang antar variabel. Mengingat bahwa ada tiga persamaan kointegrasi, persyaratan untuk pemasangan dalam model koreksi kesalahan terpenuhi.

Tabel 3 Hasil Mekanisme Koreksi Error Parsimoni

\begin{tabular}{|l|c|c|c|c|}
\hline \multicolumn{1}{|c|}{ Variabel } & Koefisien & T-Statistik & T-Tabel & Kemungkinan \\
\hline C & 0.050662 & 3.015473 & 2.04 & 0.0058 \\
\hline DLOG (MANP (-1)) & 0.236077 & 1.835277 & 2.04 & 0.0784 \\
\hline DLOG(MANP(-2)) & -0.302753 & -5.622196 & 2.04 & 0.0000 \\
\hline DLOG(EXR) & -0.054615 & -1.272250 & 2.04 & 0.2150 \\
\hline DLOG(MXP) & 0.018681 & 0.587724 & 2.04 & 0.5620 \\
\hline DLOG(MINT) & -0.025642 & -0.576511 & 2.04 & 0.5694 \\
\hline ECM(-1) & -0.875100 & -4.29528 & 2.04 & 0.0075 \\
\hline R2=0.611108 & $\begin{array}{c}\text { DW-Stat }= \\
2.004\end{array}$ & F-Stat $=6.5475$ & F-tab=3.60 & F-prob=0.0003 \\
& & & & \\
\hline
\end{tabular}

Persamaan ECM pelit disajikan demikian; ManPt $=0.050662+0.54615(E X R)+0.0186681$ (MXP) - 0.8751 (MINT) -0.8751 (ECM)

Hasil Parsimonious Error Correction Model (ECM) pada Tabel 3 menunjukkan R2 sebesar $61 \%$, artinya model dinamis sudah sesuai. Dengan demikian, variasi dalam variabel dependen mencapai 61 persen dari total variasi variabel independen. Oleh karena itu, kekuatan penjelas dari model yang diperkirakan adalah 61 persen. Selain itu, signifikansi model keseluruhan yang ditunjukkan oleh nilai f-statistik pada 6,547 mendukung kecocokan R2. Ini berarti bahwa hasil regresi secara keseluruhan adalah signifikan. Nilai Durbin Watson (DW) dari 2.004, yaitu sekitar 2.0, masalah autokorelasi serial yang disarankan tidak mempengaruhi model. Artinya bahwa nilai-nilai berturutturut dari istilah kesalahan tidak bergantung atau berkorelasi secara serial. 
Selain itu, koefisien dari istilah koreksi kesalahan muncul dengan tanda kanan (negatif) dan signifikan secara statistik pada level 5 persen. Hal ini menunjukkan bahwa sekitar 87,5 persen disequilibria output sektor manufaktur pada tahun sebelumnya terkoreksi pada tahun berjalan. Oleh karena itu, ECM dengan tepat mengoreksi deviasi dalam hubungan ekuilibrium jangka pendek ke jangka panjang antara output sektor manufaktur dan variabel penjelas (nilai tukar, ekspor manufaktur, dan suku bunga).

Furthermore, the coefficient of exchange rate (EXR) is negatively related with manufacturing sector output but statistically not significant at 5\% level. Meaning that a percentage increase in exchange rate will decrease the manufacturing sector output by 0.054615 percent. But the t-statistic at 1.272 dengan probabilitas 0,215 tidak signifikan secara statistik pada level 5 persen. Implikasi dari hasil ini adalah bahwa nilai tukar (EXR) tidak berpengaruh terhadap output sektor manufaktur. Oleh karena itu, penelitian ini menerima hipotesis nol yang mengatakan " tidak ada hubungan yang signifikan antara nilai tukar dan output sektor manufaktur di Nigeria.

Selain itu, koefisien ekspor manufaktur (MXP) berhubungan positif dengan output sektor manufaktur tetapi secara statistik tidak signifikan pada tingkat 5 persen. Artinya peningkatan persentase ekspor manufaktur akan meningkatkan output sektor manufaktur sebesar 0,018681\%. Sedangkan ekspor manufaktur tidak berpengaruh signifikan terhadap output sektor manufaktur. Oleh karena itu, penelitian ini menerima hipotesis nol yang menyatakan bahwa tidak ada hubungan yang signifikan antara ekspor manufaktur dan output sektor manufaktur di Nigeria.

Selain itu, koefisien suku bunga (MINT) berhubungan negatif dengan output sektor manufaktur tetapi secara statistik tidak signifikan dengan output sektor manufaktur. Artinya persentase kenaikan suku bunga sektor manufaktur akan menurunkan output sektor manufaktur. Secara spesifik, kenaikan suku bunga sebesar $1 \%$ akan menurunkan output sektor manufaktur sebesar $-0,025642 \%$. Karena tingkat bunga tidak berdampak pada output sektor manufaktur. Oleh karena itu, penelitian ini JURNAL PAPATUNG: Vol. 2 No. 1 Tahun 2019 
menerima hipotesis nol dan menyimpulkan bahwa tidak ada hubungan yang signifikan antara tingkat bunga dan output sektor manufaktur di Nigeria.

\section{KESIMPULAN}

Dalam studi ini, kami berangkat untuk menyelidiki secara empiris dampak nilai tukar terhadap output sektor manufaktur dalam periode 1980 sampai 2016. Beberapa variabel digunakan untuk mengeksplorasi hubungan antara nilai tukar dan output sektor manufaktur. Variabel-variabel tersebut adalah; nilai tukar, hasil produksi manufaktur, ekspor manufaktur dan tingkat bunga. Teknik utama analisis adalah metode ECM. Dari hasil ECM yang pelit, beberapa kesimpulan menarik ditarik. Pertama, ekspor manufaktur berhubungan positif dengan output sektor manufaktur di Nigeria. Sedangkan nilai tukar dan suku bunga memiliki hubungan negatif dengan output sektor manufaktur. Ini berkolaborasi dengan studi sebelumnya lainnya tentang kinerja sektor manufaktur. Selain itu, studi tersebut menunjukkan bahwa kinerja yang buruk dari output sektor manufaktur selama periode studi merupakan cerminan dari nilai tukar yang tinggi dan tingkat suku bunga untuk sektor tersebut yang menghambat peningkatan produksi. Berdasarkan temuan ini, saran berikut dapat digunakan oleh pembuat kebijakan dan peneliti dengan tujuan menjadikan sektor manufaktur Nigeria layak; Pemerintah harus merumuskan dan menerapkan kebijakan moneter yang bertujuan untuk menurunkan suku bunga sektor manufaktur. Hal ini akan memberikan kesempatan kepada produsen untuk mendapatkan akses ke pinjaman yang akan membantu mereka meningkatkan hasil produktif. Dengan demikian, subsektor manufaktur domestik yang layak akan tercapai. Kebijakan nilai tukar di Nigeria harus memberikan konsesi yang diperlukan untuk produk manufaktur dan input serta permesinan terkait untuk meningkatkan produktivitas dan daya saing sektor tersebut.

Pemerintah harus mendorong ekspor produk manufaktur dalam negeri. Ini akan meningkatkan output ekonomi Nigeria 


\section{DAFTAR PUSTAKA}

Ajayi, O. D. (2011). Runtuhnya Sektor Manufaktur Nigeria. Majalah Berita Suara. Diperoleh secara online di www.thevoicenewsmagazine.com pada 15/06/2012

Akinlo, A. E. \& Adejumo, V. A. (2014). Volatilitas Nilai Tukar dan Ekspor Nonmigas di Nigeria: 1986-2008. Bisnis dan Manajemen Sedunia, 9(2), 70-79.

Akinlo, O.O. \& Lawal, Q. A. (2015). Dampak Nilai Tukar terhadap Produksi Industri di Nigeria 1986-2010. Bisnis dan Manajemen Internasional 10 (1), 104-110

Asher, O. J (2012). Dampak Fluktuasi Nilai Tukar pada Pertumbuhan Ekonomi Nigeria (19802010). Tesis B.sc yang tidak diterbitkan dari Caritas University Emene, Enugu State, Nigeria. CBN (2014). Laporan Tahunan dan Laporan Rekening.

Central Bank of Nigeria (2017). Penjelasan tentang Penentuan Kelompok Nilai Tukar Optimum di bawah IFEM. Divisi Sektor Eksternal dari Departemen Riset.

David, U. \& Ameh, A. (2010). Pengaruh Fluktuasi Nilai Tukar pada Sektor Manufaktur Nigeria. Jurnal Afrika Manajemen Bisnis 4 (14), 2994-2998.

Ehinomen, C. \& Oladipo, T.I, (2012). Manajemen Nilai Tukar dan Kinerja Sektor Manufaktur dalam Ekonomi Nigeria. IOSR Journal of Humanities and Social Science (JHSS) ISSN: 2279-0837, ISBN: 2279-0845 5 (5)

Eme, O.A. \& Johnson, A.A (2012). Pengaruh Pergerakan Nilai Tukar pada Pertumbuhan Ekonomi di Nigeria. Jurnal Statistik Terapan BPS. 2 (2), 1-28.

Fakiyesi O. \& Akan, O. (2005). Masalah Uang, Keuangan dan Manajemen Ekonomi. Lagos: University Press

Imoughele, L.E. \& Ismaila, M. (2015). Dampak Nilai Tukar pada Ekspor Non-Minyak Nigeria. International Journal of Academic Research in Accounting, Finance and Management, 5 (1), 30-42 Johansen, S. (1998). Analisis Statistik dan Vektor Ko-integrasi. Jurnal Dinamika dan Pengendalian Ekonomi, 12 (2-3), 231-254.

Jongbo, Olajide Clement (2014). Dampak Fluktuasi Nilai Tukar Riil pada Output Industri di Nigeria, Jurnal Studi Kebijakan dan Pembangunan, 9 (1), 268-278

Ogunleye, E. K. (2008). Volatilitas Nilai Tukar dan Arus Masuk Investasi Asing Langsung di Beberapa Negara Afrika Sub-Sahara, 1970-2005. Ph.D. Disertasi. Universitas Ibadan. 
Okigbo, P.M. (1993). Esai dalam Filsafat Pembangunan Publik, Kuliah Program Penyesuaian Struktural, Vol.4, Enugu, Edisi Keempat.

Opaluwa, D; Umeh, J.C \& Abu, A.A (2012). Pengaruh Fluktuasi Nilai Tukar pada Sektor Manufaktur Nigeria. Jurnal Afrika Manajemen Bisnis 4 (14), 2994 -2998.

Owolabi, A.U \& Adegbite, T.A (2012). Pengaruh Rezim Devisa pada Pertumbuhan Industri di Nigeria. Jurnal Penelitian Lanjutan Global Ekonomi, Akuntansi dan Keuangan 1 (1), 1- 8.

Oyejide, T.A. \& Ogun, O. (1985). Program Penyesuaian Struktural dan Kebijakan Nilai Tukar dalam Masalah Kebijakan Ekonomi Makro dalam Ekonomi Berkembang Terbuka: Studi Kasus Nigeria. Publikasi NCEMA, Ibadan.

Tomola, M. O., Adedisi, T. E., \& Olawale, F. K. (2012). Pinjaman Bank, Pertumbuhan Ekonomi dan pelaksanaan Sektor Manufaktur di Nigeria. Jurnal Ilmiah Eropa, 8 (3), 19-34. 